\title{
Journal of Material Culture
}

http://mcu.sagepub.com/

Shellwork on show: Colonial history, Australian Aboriginal women and the display of decorative objects

Maria Nugent

Journal of Material Culture 2014 19: 75 originally published online 24 November 2013 DOI: 10.1177/1359183513509535

The online version of this article can be found at:

http://mcu.sagepub.com/content/19/1/75

Published by:

@SAGE

http://www.sagepublications.com

Additional services and information for Journal of Material Culture can be found at:

Email Alerts: http://mcu.sagepub.com/cgi/alerts

Subscriptions: http://mcu.sagepub.com/subscriptions

Reprints: http://www.sagepub.com/journalsReprints.nav

Permissions: http://www.sagepub.com/journalsPermissions.nav

Citations: http://mcu.sagepub.com/content/19/1/75.refs.html

>> Version of Record - Jan 21, 2014

OnlineFirst Version of Record - Nov 24, 2013

What is This? 


\title{
Shellwork on show: Colonial history, Australian Aboriginal women and the display of decorative objects
}

Journal of Material Culture 2014, Vol. 19(I) 75-92

(C) The Author(s) 2013

Reprints and permissions: sagepub.co.uk/journalsPermissions.nav DOI: 10.1 | 177/I359|835|3509535 mcu.sagepub.com

\section{Maria Nugent}

Australian National University, Canberra, Australia

\begin{abstract}
This article explores the exhibition history of decorative shell-art objects made by Aboriginal women in southeast Australia since the late Victorian era. Although produced for over a century, Aboriginal women's 'shellwork' (as it is known) has only recently received sustained curatorial attention. During the last few decades it has been acquired by private and public collectors and exhibited in both small independent and major public art galleries and museums. The article uses the contemporary curatorial interest in Aboriginal women's shellwork as an occasion to trace a longer history of its exhibition and display. A historical view reveals the 'cultural', 'aesthetic' and 'political' work that these objects performed as they were displayed in ways designed to communicate messages about their makers and to mediate social relations under colonial conditions. Earlier histories of display and its rhetorical functions are often lost, ignored or downplayed when Aboriginal women's shellwork is exhibited within contemporary exhibition spaces; but the author suggests that there is more continuity between old and new display cultures and practices than is generally acknowledged. In light of this, the article argues for greater recognition of earlier histories of display practices and visual rhetorics to inform the contemporary interpretation and exhibition of these objects. The article concludes with a recent installation of Aboriginal women's shellwork that is suggestive of this approach.
\end{abstract}

\section{Keywords}

Aboriginal women, Australia, colonialism, commodities, exhibition and display, La Perouse, museums, shellwork

\section{Corresponding author:}

Maria Nugent, Australian Centre for Indigenous History, School of History, Coombs Building (9), Australian National University, Canberra, ACT 0200, Australia.

Email: maria.nugent@anu.edu.au 
The production of decorative 'shellwork' by Aboriginal women in settlements around Sydney and along the New South Wales coast dates to the late Victorian era. Aboriginal women (and girls) made a variety of delicate shelled objects, such as baskets, letter holders, flowers, heart-shaped boxes and baby shoes, in a style that was popular among Victorian women. While it is not absolutely clear when and how Aboriginal women began to make decorative shellwork in this style, it is certain that female missionaries who lived and worked among Aboriginal people in government settlements played a part in encouraging and facilitating the practice (McKenzie and Stephen, 1987: 179-181).

As a product of the colonial encounter, this particular practice of making objects from shells needs to be distinguished from other practices that have their origins in pre-contact times. In Tasmania, for instance, Aboriginal women made necklaces and other functional items of body decoration from seashells before British colonization and continued to do so after settlement. In recent times, the practice has been revived (Greeno, 2006: 45-55).

Although shellwork was made in Aboriginal settlements along the coastal strip of New South Wales, one settlement in particular, La Perouse, situated near Sydney, was, and still remains, the major site of production (Nugent, 2005: 81-83, 2011: 71-89). Archival evidence indicates that small, shelled objects, like shell baskets and shell flowers, were being made at that settlement by Aboriginal women and girls for sale in and around Sydney in the late 1870s and early 1880s (Nugent, 2011: 76). From this time on, the practice was carried out, almost continuously, up to the present day. Contributing to its longevity at this settlement was the development of La Perouse in the early part of the 20th century as a popular tourist site that was easily accessible from the city (Nugent, 2005: 63-90). The Aboriginal settlement was among its attractions, and local Aboriginal people responded to the tourist market by making souvenirs.

Aboriginal women at La Perouse were well placed to take advantage of the new market that tourism created close to their homes. They transformed the style of shellwork they had been making for a feminine and domestic market into souvenirs and mementoes that would appeal to local and international tourists and day-trippers (Nugent, 2005: 81-83; Vanni, 2000: 400-402). In this way, La Perouse Aboriginal women's shellwork can be considered an Australian version of North American quillwork, which the Canadian art historian Ruth B Phillips has shown to be a product of the colonial encounter. Shellwork has performed analogous work in 'mediating the impact of colonialism' (Phillips, 1998: 14). Moreover, like quillwork and other 'tourist arts', it represents a rich source for interpreting and exhibiting 'transcultural' histories and aesthetics (p. 3).

Histories of the production of Victorian-era shellwork by Aboriginal women in New South Wales, and its economic and cultural values and meanings, especially to its makers, have been examined in some detail (Allas, 2006: 24-26; Martin, 2007; Nash, 2010: np; Nugent, 2011: 71-89). Far less attention, however, has been given to the contexts and modes of its display and exhibition (although see Nugent, 2012: np). This oversight is surprising because the contexts in which Aboriginal women's shellwork was shown, and the rhetorics of its display, were crucial to the social and aesthetic work that it performed. Public as well as private exhibitions and displays are, as the historian and curator Martha Sear (2000: 25) notes, a 'self-conscious orchestration of objects for a rhetorical purpose'. Shellworks' display history matters, not least because shellworks were a medium for 
messages about the identities of the women who made them and their place - actual and anticipated - in the colonial and imperial order of things.

By exploring the exhibition history of these objects, this article aims to contribute not only to scholarship on material culture, commodity production and object making as products of and sources for cross-cultural colonial histories (Jones, 2007; Phillips and Steiner, 1999). It also seeks to engage with contemporary curatorial interest, in Australia and elsewhere, in Aboriginal women's object-making practices, both past and present (see Kleinert, 2000, 2010; Reynolds, 2005; West, 2008), which was, for example, also a focus of the 2009 exhibition Tayenebe: Tasmanian Aboriginal Women's Fibre Work at the Tasmanian Art Gallery in Hobart and which subsequently toured nationally. It is only in the last few decades that this style of shellwork, made by Aboriginal women since the late 19th century, has received any curatorial attention at all. Today, though, most of the major public museums and art galleries in Australia have pieces in their collections and it is exhibited reasonably regularly. Examples of La Perouse shellwork are, for instance, currently on display at the Museum of Contemporary Art in Sydney and at the National Museum of Australia in Canberra, and others were exhibited at the Art Gallery of New South Wales in 2010 and the Australian National University in 2012 (Nugent, 2012: np).

Earlier histories of display and its rhetorical purpose are often lost or ignored when Aboriginal women's shellwork is exhibited within contemporary exhibition spaces; but I want to suggest that there is more continuity between old and new display cultures and practices than is generally acknowledged. In light of this, the article argues for the recognition of earlier histories of display practices and visual rhetorics to inform the contemporary interpretation and exhibition of these objects. To explore this, the article proceeds chronologically to trace the contexts, modes and purposes of the public exhibition of these delicate, decorative objects, while also drawing comparisons between past and present practices to reveal continuities as well as differences in the cultural, aesthetic and political work that the display of these objects has performed across time. What 'object lessons' were involved in - and can be drawn from - the exhibition of this style of Aboriginal women's shellwork in the 1880s compared with the 1980s, or the 2010s and 1910s? What contributed to this decorative object, long neglected by museums, becoming something that by the late 20th century was actively sought by them for their collections? How does the display of Aboriginal women's shellwork in late 20th-century museums articulate with its earlier display in late 19th-century colonial exhibitions of women's work? What contributed to the new assessment of this shellwork since the 1990s as Aboriginal art? What has this meant for the histories it is used to tell in various contemporary public contexts?

\section{Made for display: Early exhibition contexts}

A history of the production of Aboriginal women's shellwork is always also a history of display and exhibition, precisely because shellwork is a decorative object designed and made for show. From the outset, white women sought Aboriginal women's shellwork for display in their private homes, but it was also regularly exhibited publicly as well. Public spaces for its display included exhibitions aimed at demonstrating the value of women's work, such as women's work exhibitions and charity bazaars and fetes, as well as 
exhibitions devoted to showcasing Aboriginal people's manufactures, such as mission loan exhibitions or government-sponsored Aboriginal courts at metropolitan agricultural shows (Nugent, 2011: 77-81; Scott and Lurie, 2007: 45-62; Sear, 2000: 166, 173-176).

In the former, shellwork was on show as an object lesson in its makers' capacity to acquire the 'feminine arts of civilization' as well as evidence of the supposed fruits of missionary or other charitable intervention and influence in Aboriginal women's lives. To communicate this message, Aboriginal women's shellwork was displayed alongside similar objects made by non-Aboriginal women, because being able to make small decorative things that white women made and valued - indeed to be able to make them so that they were largely indistinguishable from similar objects made by white women - was judged not only as a measure of an individual's ability but also as encapsulating the potential of Aboriginal women themselves to become Victorian ladies (Barwick, 1974: 51-63). The meanings of shellwork derived, therefore, in part from the company it kept. Descriptions in newspapers of Aboriginal women's shellwork, for instance, typically drew comparisons between the handiwork of Aboriginal and white women to underscore this point. Display in these contexts served, then, a double purpose. To display the small and decorative was an expression of Victorian feminine tastes and sensibilities (see Phillips, 1998: 204-212); for Aboriginal women to display the decorative wares they made was to demonstrate their own capacity to acquire those tastes and sensibilities, if they were not already deemed to be in possession of them.

Yet because of the mimetic quality - the fact that it could not always be distinguished from similar objects made by women, but that the very purpose of its public display was to convey Aboriginal women's capacity for 'assimilation' - the Aboriginal women were often also required to be present within these exhibition contexts. In this situation, Aboriginal women themselves became part of the repertoire of display, in which they served as an authorizing or authenticating presence, proclaiming what the objects they made could not (Sear, 2000: 173-176).

Overlapping this phase, and then outlasting it, was the production, circulation and consumption of Aboriginal women's shellwork as a souvenir for a tourist market (Nugent, 2005: 81-83, 2011: 81-85; Vanni, 2000: 400-402). This has been quite widely discussed in the literature, although little attention has been given to the modes of display used within this sphere. Here, Aboriginal shell workers appear to have had greater control over how their wares were displayed, although it is likely that they carried into this realm some elements from the repertoire of display used in the 'feminine' contexts discussed above. At La Perouse, the usual arrangement the women used to display their handiwork was on blankets spread out on the ground at the tram terminus where crowds of tourists disembarked. This is evidenced best in photographs taken in the 1940s and 1950s (see Figure 1). These visual sources illustrate that the women's shelled objects were arranged by type and, probably, by colour within those groupings. The smallest items, in this case miniature baby shoes, were lined up at the front of the blanket; the medium-sized objects, such as heart-shaped boxes, in the middle; and the larger and more expensive and prized objects, like shelled Sydney Harbour Bridges or threedimensional maps of Australia, at the back, close to the stall holder. Mid 20th-century tourists, like genteel Victorian ladies before them, bought Aboriginal women's 


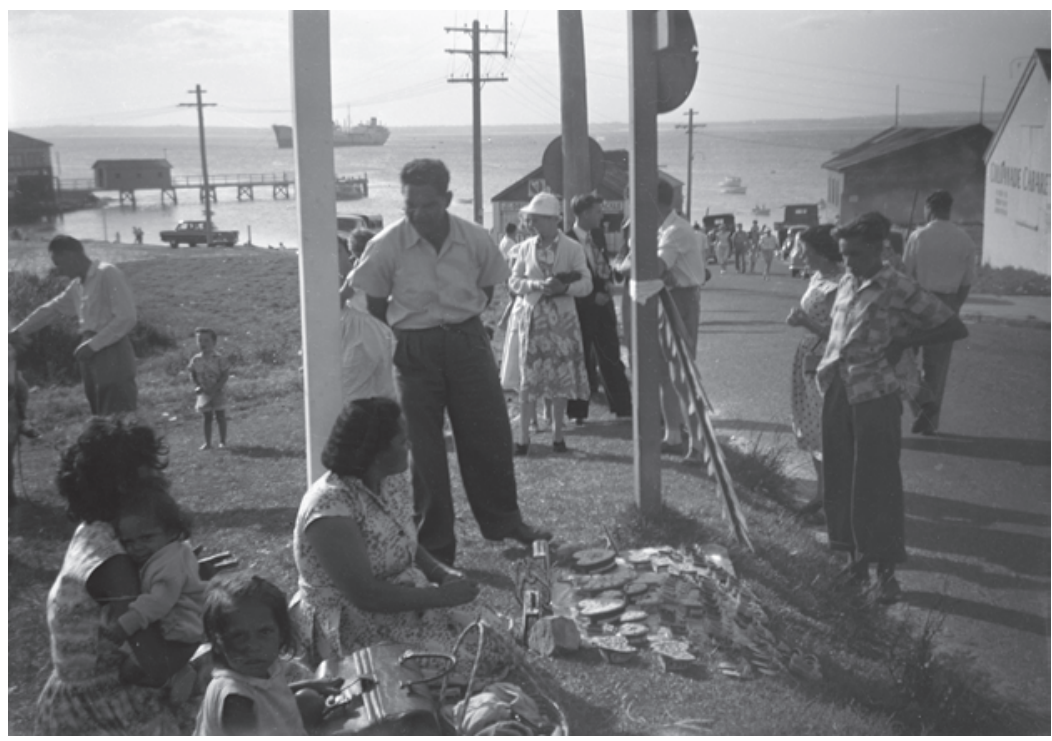

Figure I. Selling shellwork and boomerangs at the Loop, La Perouse, near Sydney, 1950s. Collection: Powerhouse Museum. Photo: J.H. Bell.

shellwork for display in their homes, as mementoes of holidays or day trips or as appealing, decorative symbols of Australia and Sydney.

Here, too, the value and meanings of Aboriginal women's shellwork relied in part on the company it kept. In this tourist context it was not displayed alongside similar objects made by white women, but with souvenirs, typically wooden boomerangs and shields, made by Aboriginal men. This company and this context helped to declare its status as souvenir, but it also demonstrates the ways in which Aboriginal women's object making had begun to draw on the forms and designs that Aboriginal men were using to decorate the wooden souvenirs they made, such as maps of Australia, native fauna and the Sydney Harbour Bridge (Nugent, 2011: 84-85). The aesthetic exchanges here were less between white women and Aboriginal women, and more between Aboriginal women and Aboriginal men. Previously, the designs had conformed to Victorian feminine preferences for decorative flowers or delicate shelled baskets, although the persistence of heart-shaped boxes and baby shoes alongside more obvious souvenir forms like maps of Australia or iconic sites such as the Sydney Harbour Bridge (opened in 1932), demonstrate continuity with this earlier phase.

The point to note, though, is that there was a spatial demarcation, however minimal, between the displays of Aboriginal women's souvenirs and those made by Aboriginal men. While women laid their objects on a blanket on the ground, men typically arranged souvenir boomerangs, shields and waddies (clubs) on specially designed poles or stands. Women sat behind their displays, often nursing or supervising children; men stood beside theirs (see Figure 1). Even when La Perouse Aboriginal souvenirs moved into more permanent establishments, such as Aboriginal family-operated shops, the demarcation in the 
display of women's objects and men's remained. The delicateness and decorative quality of shellwork was preserved by its protective presentation in glass-fronted display cabinets or high up on shelves behind the counter. Wooden boomerangs and shields, by contrast, were hung out in the open, in ways that were easy to access, not least because their sale relied on a lesson in their use.

Again, though, in these various souvenir stalls and tourist contexts, the presence of Aboriginal women alongside the objects they made for sale was vital. It remained the case that the appeal was not just the attractiveness of the object itself, but also the fact that it had been made by an Aboriginal woman, and one who lived at the place where it was purchased. The interrelationship between maker, object and place has been well established in the literature on the semiotics of souvenirs (see Jules-Rosette, 1984) and was clearly at work in the transformation of Aboriginal women's shellwork into a souvenir. Yet, on the evidence, both visual and oral, Aboriginal women seem more at ease, or 'at home', as an essential part of the show in this context than is conveyed in written descriptions of Aboriginal women in attendance at charity bazaars or women's work exhibitions in the late 19th and early 20th centuries. No doubt, this is because they were at home. The distance between where they lived and where they displayed and sold their wares to tourists, was short. Tourism took place in their backyards (for a comparable example, see Raibmon, 2003/2004: 69-89). The point of sale was so close that they could carry the little things they made at their kitchen tables in old battered leather railway bags the few hundred yards to the stalls at the tram terminus; and what they did not sell they carried home again. The smallness and thus portability of the objects was an important factor in their status as commodities.

Yet for all this history of exhibition and display, for the first hundred years of its 'social life' (Appadurai, 2005[1986]), from the 1880s to the 1980s, La Perouse Aboriginal women's shellwork was not collected or exhibited by any public museum or art gallery. Despite its reasonably long and diverse exhibition history, its history as a museum object comes late, not beginning until the mid-1980s. Various scholars have explained why museums were not interested in these and like objects, such as feather flowers, made by Aboriginal women in the colonial period (Kleinert, 1994: 152-159). Some point to judgments of them as 'inauthentically' Aboriginal, because they borrowed from or imitated white women's object-making practices, while others highlight that the production by women and for a tourist market placed these objects outside the scope of what colonial museums collected (Kleinert, 2000: 78-83; Stephen, nd). Certainly a bias in colonial Australian museums towards objects made by Aboriginal men rather than women, and for ethnographic or 'traditional' objects rather than 'colonial' or post-contact ones, meant that these decorative, feminine and 'hybrid' curiosities were not part of the foundational museum collections established in the late 19th and early 20th centuries (Peterson et al., 2008; for comparison with post-contact historical heritage in Australia, see Byrne and Nugent, 2004). This story of exclusion from museums is now well established; but less explained in relation to Aboriginal women's shellwork specifically and to other colonialera commodities made by Aboriginal women more generally, is its journey into museum storerooms or exhibition galleries (but see Coates, 2008 for a broader discussion of the relationship between collector and curator). In Australia, considerable attention has been given to this process in respect to Aboriginal visual arts (Morphy, 2007; Myers, 2002) or 
'ethnographic' objects (Griffiths, 1996; Jones, 2007; Peterson et al., 2008), but not so much has been said on the matter in relation to 'colonial commodities' or souvenirs or Victorian-era curios (but see Kleinert, 1994; Taçon et al., 2003).

\section{On becoming a museum object}

The late entry of Aboriginal women's shellwork into museums not only underscored the fact that it was not considered an 'ethnographic object', but it also meant that it was spared from becoming an 'object of ethnography' (Kirshenblatt-Gimblett, 1991: 386-433). Nevertheless, since becoming a museum object, a process that began in the mid-1980s, these objects have defied any straightforward categorization. La Perouse shellwork is, for instance, considered neither completely 'historical' or 'art' object, nor as definitively 'art' or 'craft' (Cochrane, 2007; Martin, 2007). Throughout its history, shellwork has been registered as an object variously produced, described and interpreted as curio, commodity, souvenir, decorative art, craft and, more often than not, as already suggested, as material evidence of some quality or other imputed to its makers.

Its somewhat odd, or out-of-place, character, along with the blurred boundary between its assignation as historical object and art object, was evident when it did eventually make its entry into museum collections in the late 20th century. The first museum in Australia to assemble a collection of La Perouse Aboriginal women's shellwork and to exhibit some of it, was the Museum of Applied Arts and Sciences (MAAS) in Sydney. MAAS is a complex of museums dating back to the $1880 \mathrm{~s}$, which, as its name indicates, focuses its collection, research and exhibition programmes on technology and applied science as well as decorative and applied arts. If Aboriginal women's shellwork fits anywhere, it is probably under the heading of decorative arts (see Cochrane, 2007; Isaacs, 1987). And yet this was not a particularly motivating factor for curatorial interest at MAAS in La Perouse shellwork.

The timing was critical. In 1988, the Powerhouse Museum (PHM) was a new addition to MAAS, and it heralded a new phase in its long history, one that was characterized by greater emphasis on social history (Davison and Webber, 2005). Under these conditions, MAAS's existing decorative arts collections were put to new use as well as bolstered by a new collection development programme. The employment of historians, both social and art historians, as curators, along with the influence of the 'new museology', contributed to a strong emphasis on using everyday objects, including women's material culture, to interpret, narrate and exhibit social history. Shellwork lent itself to this. At the same time, developments within the PHM were just as much influenced by social and political currents outside. The PHM was opened in 1988, the same year that Australia celebrated the bicentenary of white settlement (Davison and Webber, 2005). Questions about the representation and place of Aboriginal people in Australia's history were at the fore in public and often heated debate. La Perouse shellwork entered the Powerhouse Museum in the slipstream of these interrelated developments when it was decided to include the La Perouse Aboriginal community in one of the PHM's foundational galleries, Australian Communities (Douglas, 1991; Larbalestier, 1989: 8-11; O’Brien and Donaldson, 1989: 10). 
As is often the case, the curators involved in this exhibition project were the driving force in bringing Aboriginal women's shellwork into the museum (see Myers, 2002). For the La Perouse Aboriginal community exhibition, the curators were Ann Stephen, a respected art historian, and Peter McKenzie, an accomplished photographer who came from the La Perouse Aboriginal community. In developing the La Perouse community module for the Australian Communities exhibition, they gave particular attention to shellwork, not least because some of McKenzie's female relatives were shell workers (Taylor, 1988: 337-355). This facilitated the recording of some oral history interviews, which now provide an important historical record of shell working (Powerhouse Museum, 1986), and some of the women still practising shellwork agreed to give demonstrations at the PHM on weekends (Ryan, 2003: 12-13). Aboriginal women demonstrating in a public exhibition space how to make shellwork echoed an earlier practice, as discussed above, in which Aboriginal women became part of the display as 'live exhibits' in women's work exhibitions a hundred years earlier (Sear, 2000: 173-176). It is not clear that this element of continuity or repetition was referenced at the Powerhouse Museum, even though the women's presence served similar purposes, such as 'authenticating' the objects they made and demonstrating the 'identity' of the object via its maker, which the object itself does not proclaim loudly. Unlike the earlier demonstrations, though, this time the purpose was to illustrate to visitors that this object-making practice had a long and continuing history and was a crucial part of the La Perouse people's story of survival (Vanni, 2000: 400-402). For some visitors, presumably, this altered, or added to, the associations that decorative shellwork held for them, which, as memento, was likely to hold personal memories.

This curatorial project at the PHM resulted in what remains a peerless publicly held collection of La Perouse Aboriginal women's shellwork. The collection is broadly representative, including a number of pairs of shelled baby shoes, a selection of heartshaped boxes and some Sydney Harbour Bridges (see Figures 2 to 4), and it includes contemporary pieces made in the 1980 s as well as older ones. The collection came from two key sources. The PHM commissioned some pieces from Aboriginal women still making shellwork; others were donations from the public in response to an appeal. The latter meant that the Powerhouse collection includes some valuable historical pieces, many dating from the 1930 s to the 1950 s, which was the heyday of the production of shellwork as a souvenir, as well as a very early piece dated 1918 (Martin, 2007). Further evidence for the popularity of Aboriginal women's shellwork in this period is that the well-known and influential Australian artist and printmaker, Margaret Preston, included a piece of La Perouse shellwork in one of her still-life paintings, NSW Everlastings, dated 1929 (see Edwards, 2005: 106, 220). The fact that members of the public had pieces to donate, pieces that had been held onto for years, underlines that shellwork was already a collectible item, long before entering into a museum collection. Once these donated pieces were part of the Museum's collection, they circulated through other 'regimes of value' (Appadurai, 2005 [1986]: 4) in which their earlier collection history, or their intimate and personal memory associations, were not the focus for interpretation. In the social history museum context, Aboriginal women's shellwork was interpreted largely through the perspectives of the makers rather than buyers, even though as an object of exchange - a collectible commodity, a souvenir or 


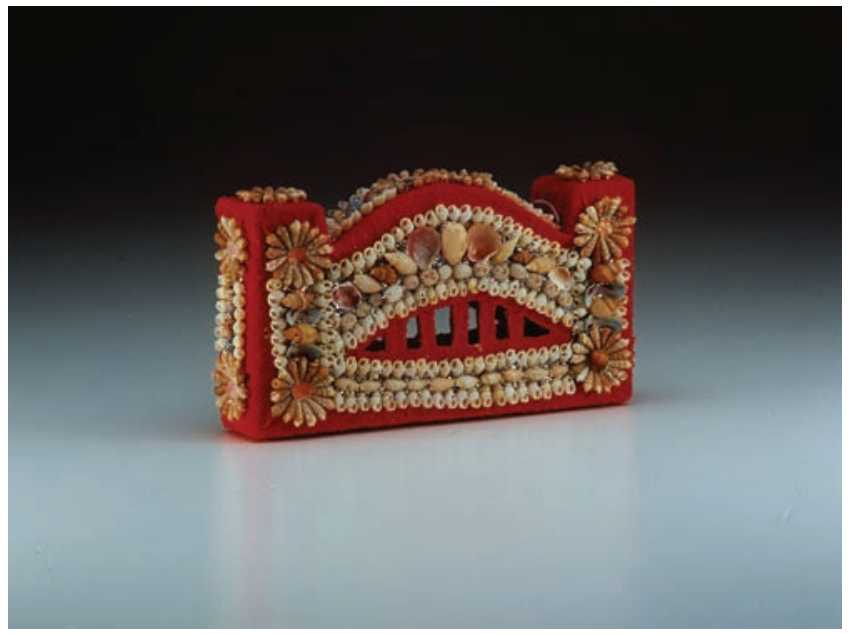

Figure 2. Shellwork Sydney Harbour Bridge, made by Mavis Longbottom and Lola Ryan, La Perouse, New South Wales, 1986. Collection: Powerhouse Museum. Photo: unknown.

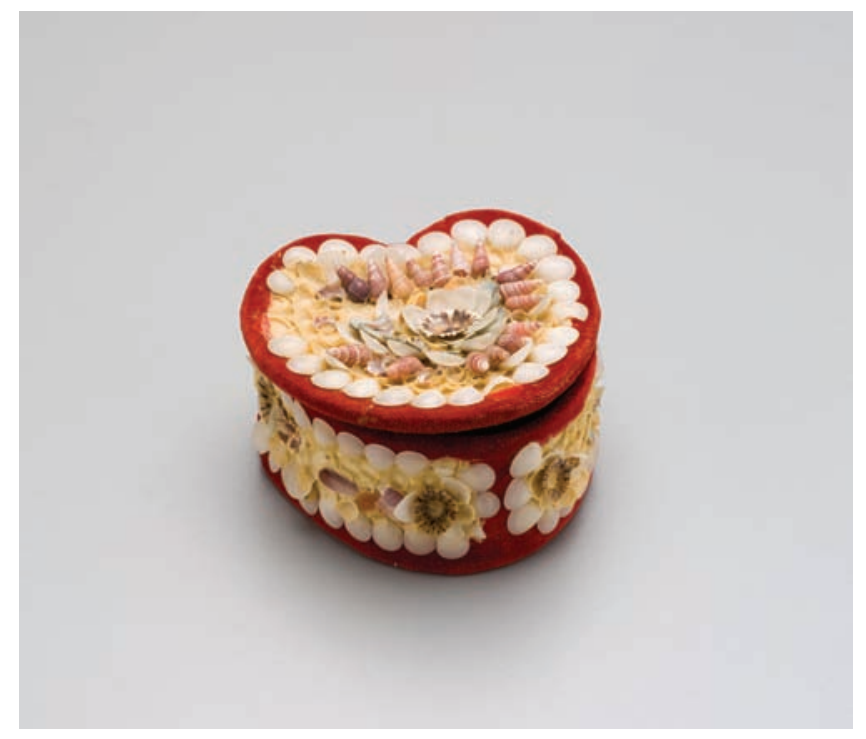

Figure 3. Shellwork heart-shaped trinket box, maker unknown, La Perouse, New South Wales, c. 1940-1945. Collection: Powerhouse Museum. Photo: Marinco Kojdanovski.

a memento - its meanings derive from both sides of the transaction and from the exchange itself (Phillips, 1998).

Nevertheless, the PHM set the standard for using these objects, previously neglected by museums, to narrate quite complex histories about Aboriginal women's negotiations of the 


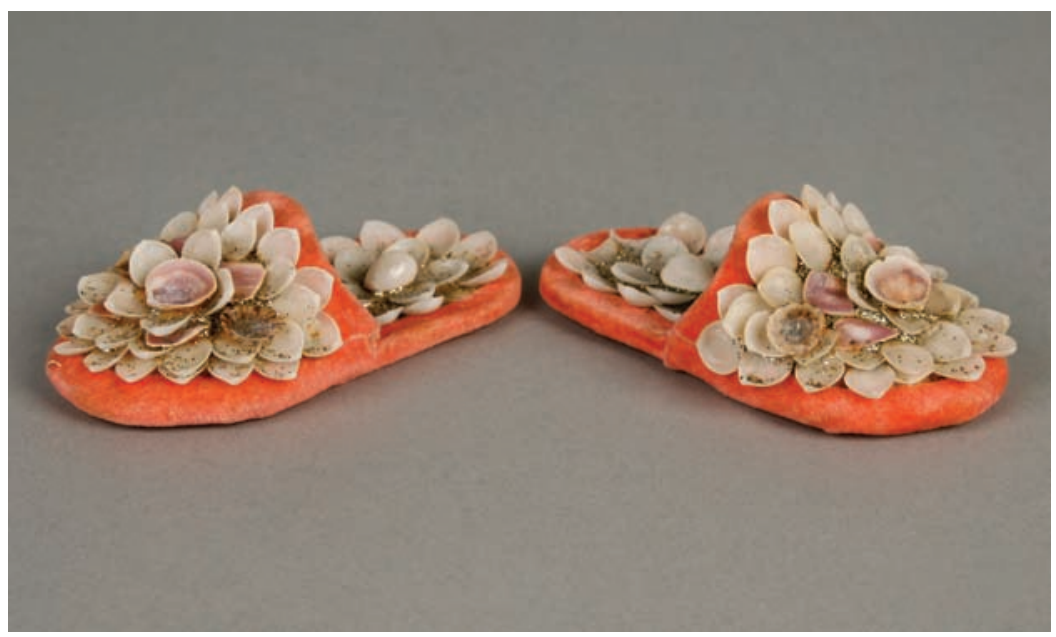

Figure 4. Shellwork baby slippers, maker unknown, La Perouse, New South Wales, c. 1952. Collection: Powerhouse Museum. Photo: Kirsten Clarke.

colonial as well as contemporary conditions under which they lived. This interpretative innovation was reflected in the exhibition; but more influentially, through various publications spawned by that curatorial project, which Stephen and McKenzie authored either together or singly (McKenzie and Stephen, 1987; Stephen, 1995). Their interpretive labours illustrated the multi-faceted meanings that these little objects held. Stephen, in particular, has stressed the object lessons shellwork provides about missionary influence on Aboriginal women's lives as well as their engagement with Victorian-era tastes and cultures (Stephen, 1995). This was complemented by emphasis on Aboriginal women's cultural and economic survival via commodity production and their participation in formal and informal cash economies (McKenzie and Stephen, 1987), along with the role that object making plays within the intergenerational transfer of knowledge and memory (Taylor, 1988; see also Individual Heritage Group, 1988). Stephen's studies of shellwork appeared in scholarly literature on Australian women's art, which anticipated as well as contributed to the new circuits through which Aboriginal women's shellwork would soon travel (Stephen, 1995).

Although it had become a museum object belatedly, this did not portend the beginning of the end for La Perouse Aboriginal women's shellwork. Indeed, the reverse was the case. This was not a museum object that provided material evidence for a past that was past. Rather, as noted, it had been used within a museum space to illustrate a past that was still living and a community still thriving, and it gained a new lease of life as a direct result. Its exhibition within the PHM, and the collateral attention it received, contributed to opening up a new trajectory as it began to be taken up in another exhibitionary context: the contemporary Aboriginal art world.

\section{On becoming art}

As had previously been the case, the circulation of La Perouse shellwork within new contexts relied at least as much on a network of interested and influential 'taste-makers' 
as it did on the women's alacrity to respond to the opportunities presented (Phillips and Steiner, 1999). By the mid 1990s, the shellwork still being made at La Perouse by just a handful of Aboriginal women began increasingly to be admired and exhibited as art. Curators and collectors are influential players in this process, as Fred Myers (2002) notes in relation to the making of Aboriginal high art, and the most significant figure in this particular instance was an Aboriginal art curator, Tess Allas. She especially championed Esme Timbery's shellwork, beginning in 1997, when she included some of her pieces in an exhibition she curated called Djalarinji - Something that belongs to us at the Manly Art Gallery and Museum in Sydney's northern suburbs. The exhibition included various contemporary 'urban' Aboriginal artists working in a range of media, such as Brook Andrew (photography) and Gordon Hookey (painting and sculpture). As Allas herself explains:

Djalarinji marked an important shift in the way the art collector viewed shellworks. No longer were they mere souvenirs for tourist consumption. From this point onwards Esme's shellworks began to be regarded as art objects worthy of discussion and collection. (Allas, 2006: 25)

As had been crucial in earlier displays of Aboriginal women's shellwork, what was exhibited alongside mattered just as much. Its fledgling status as contemporary Aboriginal art relied, not insignificantly, upon its display together with artworks that were more immediately recognizable as 'urban Aboriginal art' and which had been created by more established and well-known contemporary Aboriginal artists.

It is certainly true, as Allas notes, that in this period La Perouse shellwork drew the attention of art collectors, but it was by no means the first time it had been regarded as an art object. Discussions of it in newspapers in the early 1900s, such as in reports of its display in metropolitan agricultural shows, dwelt on its aesthetic qualities but for different reasons. The earlier emphasis on aesthetic qualities was in order to speculate about what the makers' artistic abilities signalled about their putative capacities for 'civilization' and 'assimilation' (Australian Star, 1910). As one journalist noted: 'the work of the aborigines [sic] is clear evidence of an attempt to cultivate the arts with some imagination, imitation, and a sense of beauty - all of which go towards creating the highest culture.' The writer continued this line of argument by comparing the accomplishment of this artistic endeavour to the 'crude drawings on rocks' of earlier times.

Even within the world of urban Aboriginal art, shellwork straddled boundaries and defied simple categorisation. The new crop of art collectors admiring and acquiring it in the 1990s were not necessarily collectors of decorative arts or Aboriginal art or high art, but more usually of eclectic, contemporary and 'outsider' art. For instance, in the late 1990s, the art collector Peter Fay became interested in Aboriginal women's shellwork and began to collaborate with a La Perouse shell worker, Lola Ryan (Ryan, 2003: 13). Over many years, Fay had assembled a unique collection of eclectic, quirky, 'outsider' art (Hart, 2003: 9-29). When it came to La Perouse shellwork, what appealed to Fay and other collectors like him, such as his friend and mentor Ann Lewis, was not so much its historical and contemporary association with Aboriginal women or with La Perouse, but rather the fine line between kitsch and art that was so often ascribed to it (Pakula, 2007). And so, when the National Gallery of Australia staged an exhibition called Home Sweet Home in late 2003 and early 2004 dedicated to Peter Fay's collection, some of Lola 


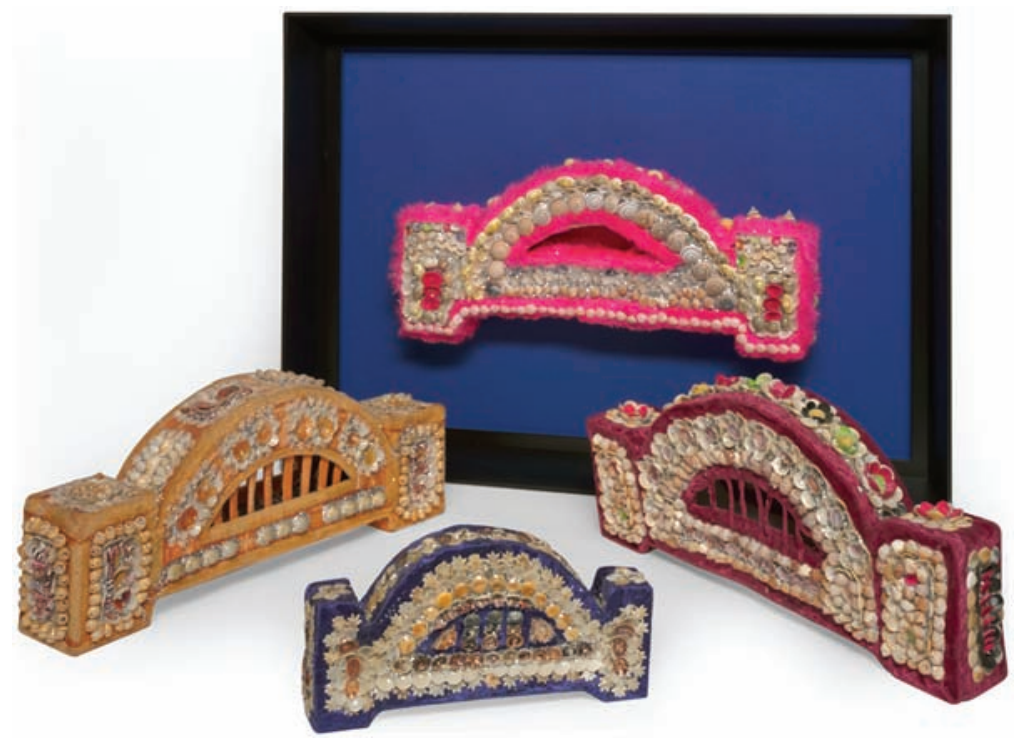

Figure 5. 'Harbour Bridge' works, made by Lola Ryan, La Perouse, New South Wales, 2000. National Gallery of Australia, Canberra, Gifts of Peter Fay, 2005 and the late Dr Joan Kerr, 2006.

Ryan's shellwork pieces were exhibited (Figure 5) (they are now part of the NGA's collection through donation from Fay). Once more, the company the collection kept was an important influence on how it was interpreted. Lola Ryan's quirky and flamboyant shellwork pieces sat easily beside other three-dimensional art objects by non-Aboriginal artists in Fay's collection, all of which revelled in lavish, vivid and outlandish decoration of ordinary and found objects (Hart, 2003: 16, 27).

In 2005, the status of La Perouse shellwork as contemporary Aboriginal art object reached a pinnacle when Esme Timbery won the inaugural New South Wales Parliament's Indigenous Art award for a blue velvet Sydney Harbour Bridge (see Perkins, 2005). This accolade announced shellwork's 'arrival' as Aboriginal art. While in competition with some more established and recognized Aboriginal artists in New South Wales, Esme Timbery's shellwork pieces were seen to encapsulate the spirit of the award. The judges explained that they were looking for 'works that were stylistically distinctive to NSW', and their rationale for selecting Timbery's piece was the ways in which it 'celebrates a contemporary icon of NSW in the traditional shellwork style associated with the La Perouse community that figures of prominently in our [i.e. NSW's] Indigenous History' (New South Wales Parliament, 2005: 5). This was artwork that pleased parliamentarians and Aboriginal curators alike, because it gave material and aesthetic form to Aboriginal people's histories, experiences and object-making traditions and practices through the decoration of a highly recognizable symbol of Sydney and New South Wales. This was not so far removed from what had made this style of shellwork attractive as a Sydney souvenir in the middle part of the 20th century. The discourse here, as previously, combined ideas 


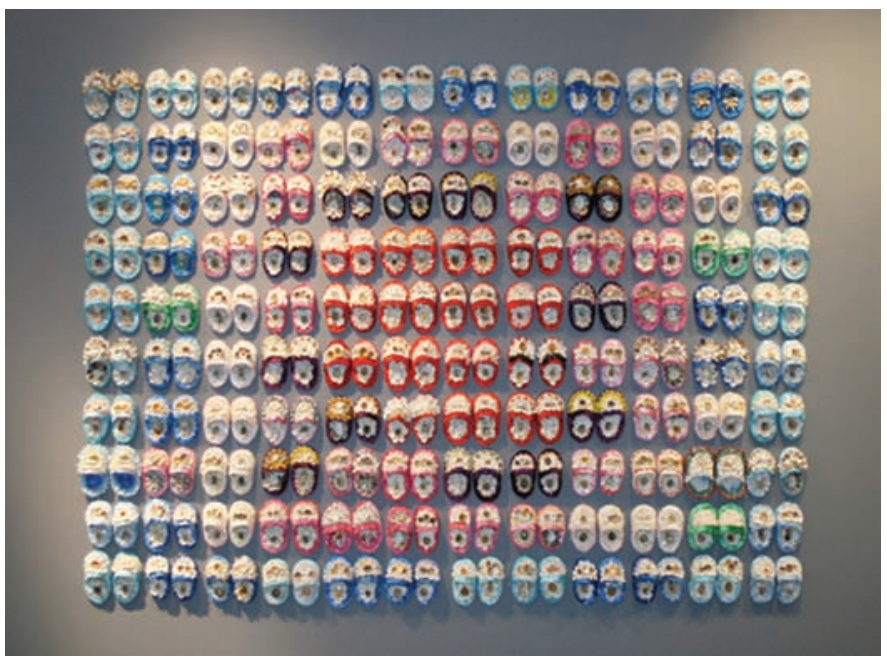

Figure 6. Esme Timbery, Shellworked slippers, 2008. Museum of Contemporary Art, Sydney, purchased with funds provided by the Coe and Mordant families, 2008. (C) the artist, licensed by Viscopy.

about the maker's aesthetic ability with expressions of her cultural identity that are intimately connected to place.

Up to this point in time, it was individual pieces of shellwork made by individual Aboriginal women that were regarded as artworks, even if their meaning as such depended in part on where they were exhibited and what was exhibited alongside. However, a recent exhibition has stretched the meanings and possibilities of shellwork as art, opening out its potential as a medium for histories and commentaries on the crosscultural contexts within which it has so long been embedded. In 2008, a leading Aboriginal art curator, Djon Mundine, curated an exhibition called Ngadhu, Ngulili, Ngeaninyagu - A Personal History of Aboriginal Art in the Premier State (Campbelltown Arts Centre, 2008). The subtitle is a nice play-on-words, because the exhibition presented Mundine's singular personal vision of Aboriginal art; and all the artworks he presented, whether from the 19th, 20th or 21st centuries, are personal responses by Aboriginal artists to their lives and experiences under colonial conditions that necessarily also speak to larger historical themes.

This is true for the La Perouse shellwork that was included within the exhibition. For this show, Mundine commissioned Esme Timbery and her daughter Marilyn Russell to make 200 pairs of shelled baby shoes (although only 120 pairs were made in time for the show), which were displayed en masse in series of neat rows (Figure 6) (Nash, 2010: np). This was a particularly perceptive and clever example of curatorship, in which the objects became a piece of art mainly through the form and language of display and assemblage. Mundine works as an independent curator and has been responsible for a series of exhibitions that bring together Aboriginal artists, past and present, sometimes around a common theme, in ways that create a space for critique and commentary on history, politics, identity and art in settler-colonial Australia. 
Working in this way belongs to broader developments in curatorship that have been in train since the 1990s, as discussed by Paul O'Neill (2008) and which he argues were accompanied by the emergence of the curator 'who has a more creative and active part to play within the production of art itself' (p. 15).

Mundine's collaboration with Esme Timbery is a good example. By displaying many small pieces of shellwork, rather than one singular piece, Mundine's curated installation suggested multiple historical and contemporary associations, as well as aesthetic and artistic reference points. At one level, as Daphne Nash (2010) notes, the little baby-sized shoes arranged in rows evoke the history of the Stolen Generations, the widespread practice in Australia whereby Aboriginal children were removed by government authority from their families (for a history of the practice, see Read, 1982). In this installation, the rows of empty shell booties lined up along a wall served as reminders of babies and small children taken away from their Aboriginal mothers. Discussion about the legacy of the practice of Aboriginal child removal has dominated public debate in the early 21 st century and culminated in a prime-ministerial apology in 2008 (Haebich, 2000; Kennedy, 2001: 116-131; Manne, 2001), so this particular historical reference point seems obvious. In commentary, Mundine has underlined this connection, pointing out that Esme Timbery's family had experienced the tragic history of child separation (see Nash, 2010). In this way, the artwork might be regarded as an example of 'trauma art' in that it provides 'a kind of visual language of trauma and of the experience of ... loss' (Bennett, 2005: 2; see also Dubois Shaw, 2006: 158-186. For a discussion of trauma in Stolen Generations testimony, see Kennedy, 2001: 116-131). The rows upon rows of delicately made, femininely decorated and miniaturized shoes provoke an affective response to this difficult history of forced child removal (see Stewart, 1993, on the affects of the miniature). Using the motif of a mass of empty shoes evokes the mountain or pile of shoes on display at Auschwitz that bears witness to another history of genocidal acts and processes of cultural destruction (Nash, 2010).

However, forced child removal is not the only aspect of colonial history that the work might be said to engage with. Less obvious, but just as important, is the way in which it appears to be in conversation with contemporary Indigenous art practices in other settler-colonial contexts, like Canada, and especially with work engaging with other aspects of colonial dispossession. Shoes again prove to be powerful objects with which to work artistically and critically for these other histories. The North American First Nations artist Gerald McMaster comes to mind, who in 1994 'installed dozens of pairs of moccasins from the National Museum of the American Indian's (NMAI) collection in a spiral, their toes and heels bent and tilted into the positions of dancing feet' (Phillips, 2005: 96). McMaster described his sadness at first at seeing the Museum's huge collection of shoes, estimated to be 2000 pairs. Shoes, like other garments, are such intimate objects, once worn and through wear acquiring the bodily contours of their wearers. Within a museum collection, though, they have been removed from personal ownership, and in that context they are used to stand for or in for something else altogether (see also Gough, 2006: 10-12). But as he engaged with the NMAI collection, McMaster says that the 'moccasins and other kinds of footwear became a metaphor for the diversity and creativity of indigenous peoples' (McMaster, 1994: 113-116). In this way, art installations like this are comments not 
only on colonial experience, but also on the history of collecting and museums that are so central to colonising projects and colonial cultures (Clifford, 1988; Lavine and Karp, 1991). Ruth B Phillips (2005: 102-106) interprets these artistic engagements as a kind of performance that takes place within the space of the 'museum-as-theatre', in which material culture collections are re-presented in challenging and provocative ways, part of a dialogue staged by urban and contemporary indigenous artists as an ongoing critique of white culture.

Yet in displaying an object that had not been collected by colonial museums, but rather ignored by them, Mundine's installation evokes a different but no less powerful engagement with the meanings of certain objects and of exhibition practices within colonial as well as contemporary economies of display, consumption and desire. Arranged in neat rows, organised by colour, within a rectangular shape, Mundine has taken Aboriginal shell workers' own modes of display and turned them into art. This is exactly how shellwork was put on show by the women who made it. They laid it out in rows on a blanket spread out on the grass at the tram terminus at La Perouse each weekend, or by the side of the road in other nearby suburbs, ready to sell to passers-by (Ryan, 2003: 12). In their commodity production, in their display practices and in their sale spiels, like colonised people throughout the world who made commodities in order to survive under new conditions, Aboriginal women engaged with and negotiated the tastes and desires of non-Aboriginal consumers. In this particular art installation, Mundine has effectively picked up a blanket of shellwork wares and hung it on an art gallery wall, and in this new form Aboriginal women's shellwork becomes available for a different kind of consumption - as contemporary Aboriginal (or Indigenous) art. Not only was it consumed by the exhibition-goers who passed through the gallery's doors, but it was immediately bought by another major public art gallery, the Museum of Contemporary Art (MCA) in Sydney, where it was exhibited in late 2008 as part of the MCA's annual new acquisitions exhibition. It is now a more permanent and prominent feature, occupying a long wall in a new wing of the MCA devoted to exhibiting Aboriginal art. This installation includes the complete complement of 200 pairs of baby shoes that Mundine had originally commissioned.

Mundine's clever curatorship of the kind of shellwork that Aboriginal women at La Perouse have been making since the late Victorian era, and primarily for sale as curios and souvenirs, not only registers its recently acquired status as contemporary Aboriginal art. What this curatorial collaboration also creates is a welcome space for critical reflection on the ways in which the practices and rhetorics of the display of these objects have mediated, and indeed continue to mediate, colonial histories, experiences and relations. This adds an important new dimension to interpreting the history of shellwork and other commodity production by Aboriginal women in colonial and 'post-colonial' contexts, complementing the already rich scholarship on the nature of production, circuits of exchange and transformations in design and appraisal. Most importantly, it serves as a timely reminder that practices of display were a critical component of the social, aesthetic and political work that shellwork performed, and performs still, in cross-cultural and settler colonial contexts.

\section{Funding}

This research was supported by an Australian Research Council Future Fellowship (FT100100073). 


\section{References}

Allas T (2006) Esme Timbery. Art Monthly Australia 187: 24-26.

Appadurai Arjun (ed.) (2005[1986]) The Social Life of Things: Commodities in Cultural Perspective. Cambridge: Cambridge University Press.

Australian Star (1910) Miscellaneous exhibits: The Aborigines. April.

Barwick D (1974) And the lubras are ladies now. In: Gale F (ed.) Woman's Role in Aboriginal Society. Canberra: Australian Institute of Aboriginal Studies, 51-63.

Bennett J (2005) Empathic Vision: Affect, Trauma, and Contemporary Art. Palo Alto, CA: Stanford University Press.

Byrne D and Nugent M (2004) Mapping Attachment: A Spatial Approach to Aboriginal PostContact Heritage. Hurstville, NSW: Department of Environment and Conservation.

Campbelltown Arts Centre (2008) Ngadhu, Ngulili, Ngeaninyagu: A Personal History of Aboriginal Art in the Premier State. Campbelltown, NSW: Campbelltown City Council.

Clifford J (1988) The Predicament of Culture: Twentieth-Century Ethnography, Literature and Art. Cambridge, MA: Harvard University Press.

Coates I (2008) The dynamics of the collector-curator relationship: Interpreting Henry Hillier's Central Australian collections. In: Peterson N et al. (eds) The Makers and Making of Indigenous Australian Museum Collections. Melbourne: Melbourne University Press, $235-254$.

Cochrane G (2007) Cross-over: Two-way influences in contemporary Indigenous design. In: Perkins H et al. (eds) One Sun, One Moon: Aboriginal Art in Australia. Sydney: Art Gallery of New South Wales, 261-269.

Davison G and Webber K (2005) Yesterday's Tomorrows: The Powerhouse Museum and its Precursors, 1880-2005. Sydney: Powerhouse Museum/UNSW Press.

Douglas L (1991) Australian Communities. Sydney: Powerhouse Museum.

Dubois Shaw G (2006) The 'rememory' of slavery: Kara Walker's The End of Uncle Tom and the Grand Allegorical Tableau of Eva in Heaven. In: Saltzman L, Rosenberg E (eds) Trauma and Visuality in Modernity. Lebanon, NH: University Press of New England.

Edwards D (2005) Margaret Preston. Sydney: Art Gallery of New South Wales.

Gough J (2006) Being collected and keeping it real. In: Reynolds AJ (ed.) Keeping Culture: Aboriginal Tasmania. Canberra: National Museum of Australia Press, 9-20.

Greeno L (2006) Maireener: Tasmanian Aboriginal shell necklaces. In: Reynolds AJ (ed.) Keeping Culture: Aboriginal Tasmania. Canberra: National Museum of Australia Press, 45-55.

Griffiths T (1996) Hunters and Collectors: The Antiquarian Imagination in Australia. Melbourne: Cambridge University Press.

Haebich A (2000) Broken Circles: Fragmenting Indigenous Families 1800-2000. Fremantle, WA: Fremantle Arts Press.

Hart D (2003) Home Sweet Home: Works from the Peter Fay Collection. Canberra: National Gallery of Australia.

Individual Heritage Group (1988) La Perouse: The Place, the People and the Sea. Canberra: Aboriginal Studies Press.

Isaacs J (1987) The Gentle Arts: 200 Years of Australian Women's Domestic and Decorative Arts. Sydney: Lansdowne.

Jones P (2007) Ochre and Rust: Artefacts and Encounters on Australian Frontiers. Adelaide: Wakefield Press.

Jules-Rosette B (1984) The Message of Tourist Art. New York: Plenum Press.

Kennedy R (2001) Stolen generations testimony: Trauma, historiography, and the question of 'truth'. Aboriginal History 25: 116-131. 
Kirshenblatt-Gimblett B (1991) Objects of ethnography. In: Karp I, Lavine SD (eds) Exhibiting Cultures: The Poetics and Politics of Museum Display. Washington, DC: Smithsonian Institution Press, 386-443.

Kleinert S (1994) 'Jacky Jacky was a Smart Young Fella': A study of art and aboriginality in South East Australia 1900-1980. Unpublished PhD thesis, Australian National University.

Kleinert S (2000) Writing craft/writing history. Humanities Research 7(1): 77-96.

Kleinert S (2010) Clothing the postcolonial body: Art, artifacts and action in South-Eastern Australia. craft + design enquiry 2: 1-34.

Larbalestier J (1989) Aborigines on exhibition. Bulletin of the Olive Pink Society 1(2): 8-11.

Lavine SD and Karp I (eds) (1991) Exhibiting Cultures: The Poetics and Politics of Museum Display. Washington, DC: Smithsonian Institution Press.

Manne R (2001) In Denial: The Stolen Generations and the Right. Tullamarine, VIC: Bolinda Publishing.

Martin K (dir.) (2007) She Sells Seashells [television documentary]. Sydney: ABC.

McKenzie P and Stephen A (1987) La Perouse: An urban Aboriginal community. In: Kelly M (ed.) Sydney: City of Suburbs. Sydney: NSW University Press, 172-191.

McMaster G (1994) Gerald McMaster: Discovering the levels of meaning. In: West WR (ed.) All Roads Are Good: Native Voices on Life and Culture. Washington, DC: Smithsonian Institution Press/National Museum of the American Indian, 113-121.

Morphy H (2007) Becoming Art: Exploring Cross-Cultural Categories. Oxford: Berg.

Myers F (2002) Painting Culture: The Making of an Aboriginal High Art. Durham, NC: Duke University Press.

Nash D (2010) From shell work to shell art: Koori women creating knowledge and value on the south coast of New South Wales. craft + design enquiry 2: np. Available at: http://www. craftaustralia.org.au/cde/index.php/cde/article/viewFile/17/16 (accessed 7 November 2011).

Nugent M (2005) Botany Bay: Where Histories Meet. Sydney: Allen \& Unwin.

Nugent M (2011) 'You really only made it because you needed the money': Aboriginal women and shellwork production, 1870s to 1970s. Labour History 101: 71-89.

Nugent M (2012) Displaying the decorative: An exhibition history of La Perouse Aboriginal women's shellwork. reCollections: A Journal of Museums and Collections 7(2): np. Available at: http://recollections.nma.gov.au/issues/volume_7_number_2 (accessed 12 November 2012).

O'Brien J and Donaldson J (1989) Powerhouse, Museum of Applied Arts and Sciences. Sydney: MAAS.

O’Neill P (2008) The curatorial turn: From practice to discourse. In: Sedgwick M, Rugg J (eds) Issues in Curating Contemporary Art and Performance. Bristol: Intellect, 13-28.

Pakula K (2007) Shells bridge the gap between kitsch and art. Sydney Morning Herald, LIFE, 6-8 April: 26.

Perkins H (2005) Parliament of New South Wales Indigenous Art Prize. Campbelltown, NSW: Campbelltown Arts Centre.

Peterson N, Allen L and Hamby L (eds) (2008) The Makers and Making of Indigenous Australian Museum Collections. Melbourne: Melbourne University Press.

Phillips RB (1998) Trading Identities: The Souvenir in Native North American Art from the Northeast, 1700-1900. Seattle/Montreal: University of Washington Press/McGill-Queen's University Press.

Phillips RB (2005) Re-placing objects: Historical practices for the second museum age. Canadian Historical Review 86(1): 83-110.

Phillips RB and Steiner C (1999) Art, authenticity and the baggage of cultural encounter. In: Phillips RB, Steiner C (eds) Unpacking Culture: Art and Commodity in Colonial and Postcolonial Worlds. Berkeley: University of California Press, 3-19. 
Powerhouse Museum, La Perouse Aboriginal Community Oral History Collection, MRS 278/1-9.

Raibmon P (2003/2004) Living on display: Colonial visions of Aboriginal domestic spaces. British Columbia Studies 140: 69-89.

Read P (1982) The Stolen Generations: The Removal of Aboriginal children in New South Wales, 1883 to 1969. Sydney: NSW Ministry of Aboriginal Affairs.

Reynolds A, in collaboration with Couzens D et al. (2005) Wrapped in a Possum Skin Cloak: The Tooloyn Koortakay Collection in the National Museum of Australia. Canberra: NMA Press.

Ryan L (2003) Shellwork: From bridges to maps. In: Steppin' Out and Speakin' Up. Millers Point, NSW: Older Women's Network NSW.

Scott J and Lurie R (2007) Colonialism on display: Indigenous people and artefacts at an Australian agricultural show. Aboriginal History 31: 45-62.

Sear M (2000) Unworded proclamations: Exhibitions of women's work in colonial Australia. Unpublished $\mathrm{PhD}$ thesis, University of Sydney.

Stephen A (nd) Jane and Olive Simms. Design and Art Australia Online. Available at: http://www. daao.org.au/bio/jane-and-olive-simms/ (accessed 7 November 2011).

Stephen A (1995) Jane and Olive Simms. In: Kerr J (ed.) Heritage: The National Women's Art Book: 500 Works by 500 Australian Women Artists from Colonial Times to 1955. Sydney: Craftsman House, 449-450.

Stewart S (1993) On Longing: Narratives of the Miniature, the Gigantic, the Souvenir, the Collection. Durham, NC: Duke University Press.

Taçon P, South B and Hooper SB (2003) Depicting cross-cultural interaction: Figurative designs in wood and stone from south-east Australia. Archaeology in Oceania 38(2): 89-101.

Tayenebe: Tasmanian Aboriginal Women's Fibre Work (2009). Hobart: Tasmanian Art Gallery. Taylor P (1988) La Perouse: Photographs by Peter McKenzie. In: Taylor P (ed.) After Two Hundred Years: Photographic Essays of Aboriginal and Islander Australia Today. Cambridge: Cambridge University Press, 337-355.

Vanni I (2000) Bridging the gap: The production of tourist objects at La Perouse. In: Kleinert S, Neale M (eds) Oxford Companion to Aboriginal Art and Culture. Melbourne: Oxford University Press.

West M (ed.) (2008) ReCoil: Change and Exchange in Coiled Fibre Art. Darwin: Artback Northern Territory Arts Touring.

\section{Author biography}

Maria Nugent is a Research Fellow based in the Australian Centre for Indigenous History at the Australian National University. 